Nevşehir Bilim ve Teknoloji Dergisi Cilt 6(2) 619-632 2017

DOI: 10.17100/nevbiltek.263972

URL: http://dx.doi.org/10.17100/nevbiltek.263972

Investigation of the Relationship between the Various Structural Parameters and Performance Displacement by Using Improved Displacement Coefficient Method

\author{
Hakan KARACA* \\ Local Directorate of Disaster and Emergency Management Presidency, Nigde, Turkey
}

\begin{abstract}
The need to express the earthquake damage in terms of the exposed level of ground motion; pushed the researchers to find a reliable and quick-to-apply method. In an effort to quantify the damages, fragility curves are introduced which are based on statistical evaluation. In the derivation of the fragility curves for buildings, the number of story is used as the main grouping parameter. However, since there isn't an explicit form of equation relating the number of stories to the damage, this common approach requires further investigation. In this study, not only the influence of the number of story on the damage but also the influence of the various parameters of the buildings, such as fundamental period, ductility ratio and lateral stiffness index are investigated. Improved Displacement Coefficient Method (IDCM) is used to obtain the lateral performance of the building in terms of roof displacements and global drift ratios. At the end of the study of the study, it is proven that fragility curves are sensitive to the mentioned parameters; however, it is very dependent on the compiled database.
\end{abstract}

Keywords: Number of story, fundamental period, ductility, lateral stiffness index, fragility

\title{
Geliştirilmiş Deplasman Katsayı Yöntemi (GDKY) Kullanarak Bazı Yapısal Parametreler ile Depremsel Hasar Arasındaki İlişkinin Araştırılması
}

$\ddot{O ̈ z}$

Deprem hasarı ile yer hareketi büyüklüğü arasındaki bağıntıyı açıklamak için araştırmacılar güvenilir ve hızlı yöntemler aramaktadırlar. Hasarın nicelik olarak ifade edilmesi için, tamamıyla istatistiksel verilere dayanan hasar görebilirlik eğrileri geliştirilmiştir. Bu eğrilerin elde edilmesi sırasında, genellikle yapıların kat sayıları göz önüne alınarak sınıflandırılma yapıldığı bilinmektedir. Ancak, yapı kat sayıları ile hasar arasında herhangi bir bağıntı geliştirilmediğinden de anlaşılır ki, bahsi geçen yaklaşımın doğruluğu hala sorgulanmaya açıktır. Bu çalışmada da, sadece bu bağıntının olup olmadığı değil, hasar ile doğal titreşim periyodu, süneklik ve yanal rijitlik katsayısı arasında herhangi bir bağıntı olup olmadığı araştırılmıştır. Geliştirilmiş Deplasman Katsayıları Yöntemi (GDKY) kullanılarak yanal ötemeler hesaplanmış ve çatı katı ötelemesi ile öteleme oranı elde edilmiştir. Çalışma sonunda, hasar görebilirlik eğrilerinin, bahsi geçen yapısal parametrelerle ilişkili olduğu anlaşılmış ancak bu ilişkinin, kullanılan veri tabanına ve yapıların dağılıma bağlı olduğu belirtilmiştir.

Anahtar Kelimeler: Kat sayısı, doğal titreşim periyodu, yanal rijitlik katsayısı, hasar görebilirlik

"e-mail: karaca26@hotmail.com, hakan.karaca@afad.gov.tr 


\section{Karaca H.}

\section{Introduction}

Various methods were proposed to evaluate the building performances and so the vulnerabilities in terms of certain structural characteristics. The subject is open to new developments and new methods are introduced continuously, however the basic understanding and background motivation is not much subjected to change. Hence, commonly the methods based on observed damage [1], expert opinion [2], simple analytical procedures $[3,4,5]$ score assignment $[6,7,8,9$ and the references therein) and detailed analysis procedures [4], are applied to derive such relationships between the building performance and certain structural characteristics.

In all the studies to determine the building performances, certain structural features are utilized to characterize the buildings. While structural features such as building height and number of stories are widely utilized, structural features such as fundamental period and ductility, which require analysis to derive, are utilized in analytical analysis. In this study, analytical studies were conducted to determine the building seismic performance and the dependency of the performance to the structural features of number of story, fundamental period, ductility and lateral stiffness index, which is the ratio of the total inertia of columns in a single storey to the total floor area bounded by structural frame, were checked.

Studies were conducted to find the relationships between the mentioned structural features, the number of story, fundamental period, ductility ratio, lateral stiffness index, and the lateral performance in terms of displacement [10 and references therein]. The mentioned building parameters have a direct or indirect influence over the lateral performance. The fundamental period of a structure is essential in predicting the lateral displacement, and therefore in predicting the seismic damage. Considering that, the total height is one of the most influential parameters that determine the fundamental period of a structure, it is automatically deduced that the proposed structural parameter of number of storeys, which could be expressed in terms of the total height, have highly correlated relationships with the lateral performance. It should be added that, most of the simple period-height relationships are derived for force based design [11], therefore with the addition of the ductility parameter, a more reliable lateral displacement prediction is possible.

The ductility ratio, with its dependence to the fundamental period [11] indirectly affects the lateral performance in terms of displacement, such that with more ductility, higher inelastic deformation is expected [12]. Lateral stiffness index [13] has a more complicated influence over the lateral displacement such that increasing the index by increasing the size of the columns causes a greater increase in the overall lateral stiffness of the structure than that in the total mass of the structure. Therefore, the fundamental period of the structure becomes smaller, which in turn decreases the demand displacement exponentially [10]. In a number of studies [14, 15,16], the influence of the ratio of the shear wall area to the total floor area on the lateral displacement is proved to be exponential, which indicates the existence of such a relationship between the lateral stiffness index and the lateral displacement.

All the parameters mentioned in the above paragraphs have implicit relationships with the lateral displacement. Consequently, to prove the existence of the relationships, statistics is required such that a sample building database is created and the dependence of the lateral performance to the mentioned parameters is sought. As a creative solution to the problem, the fragility curves offer a statistical interface where the dependency of the lateral performance to the mentioned parameters can be monitored. In the 
generation of the fragility curves, generally lognormal distribution is assumed in the modeling of lateral performances [17].

Because the lateral performance is dependent on the intensity,frequency and duration of the ground motion, and the type of the structures subjected to the ground motion, it is not yet clear that, which of the ground motion intensity is more successful in the development of fragiliy curves. Therefore, researchers used several different ground motion intensity measure in the development of fragility curves [18]. Various researchers $[19,20,21,22,23,24]$ who studied Turkish structures mostly used spectral acceleration and displacement, peak ground acceleration and peak ground velocity as ground motion intensity. Before deciding on the best fitting ground motion intensity measure, it should also be noted that, since peak ground amplitudes do not sufficiently express the parameterts of the ground motion that causes the seismic damage than spectral intensities, among the several ground motion intensity measures, spectral acceleration is used as IDCM is employed to obtain the lateral performances in terms of roof displacement and global drift ratio.

Eventually, after the analysis and evaluation, the influence of the building sample over the parameter dependency of lateral performance is revealed. Especially, the lateral performance and number of storey relationship, which commonly referred as proportional, is questioned. Regardless of the size of the sample, the proportionality of the lateral performance to the number of story could be dependent on the other structural parameters as well. Hence it can be stated that, one should be careful in relying on the common conceptions that are not explicitly proven.

\section{Database}

Turkish building stock consists of two main types of structures: buildings with reinforced concrete frames and buildings with stone/brick masonry as the load carrying system. There is already a strong trend in the construction industry that newly built structures are mostly reinforced concrete frame structures both as replacement to the older type of buildings and as new built dwellings. Therefore, when considering a general situation in the construction industry and existing building stock, reinforced concrete structures must be carefully examined in detail. In this study, a database is gathered, which consists of several reinforced concrete structures that are arbitrarily selected from the city of Eskisehir. In the selection process, a number of criteria are imposed in terms of number of stories and structural types. The number of stories is limited between 4 and 6 stories, which in fact represents a very large portion of the buildings in Eskisehir and in Turkey [ ]. Moreover, only moment resisting frame and shear walled frame structures are considered. A total of $\mathbf{2 7}$ structures are gathered, which are arbitrarily chosen to avoid any bias that could arise due to similarities between certain structural parameters.

All the structures are modeled in three dimensions by using SAP2000 program [25]. In the modeling of the structures, conventional beam-column frame modeling assumption is used. Primary and secondary structural elements are identified, and secondary structural elements such as infill walls are excluded from the models. Plastic hinges are assigned to the member ends to model the flexural response in beams and to model the biaxial flexural response under axial loads in columns. Most shear walls are designed to resist high shears and designed to fail first in flexural mode to avoid the undesired consequences in an earthquake, so after necessary checks it is decided that it is reasonable to model these 
walls only with biaxial flexural hinges. In the analysis, the default force-displacement characteristics of plastic hinges that are based on [26] and [27] criteria are utilized to perform pushover analyses. The shear walls are modeled as mid-pier columns, and two rigid beams connected to the neighboring beams. The slabs are modeled as diaphragms that transfer axial loads between the adjacent frames. The interaction of the neighboring frames is allowed with this model, but the in plane and out-of-plane bending is restricted. The same vertical loads are assigned to all the structures to reduce the variance in lateral performance that could be caused by the different vertical loads. Dead and live loads are assumed as 300 and $200 \mathrm{~kg} / \mathrm{m}^{2}$, respectively. A wall load of $1050 \mathrm{~kg} / \mathrm{m}$ is assigned to each beam element.

\section{Analysis}

The structures are subjected to lateral loading in the form of dominant mode shape in both directions, and the resultant pushover curves are obtained for both directions. All the pushover curves are generated by monitoring the displacements at the center of masses of the roof storeys of the structures. The generated pushover and capacity curves are plotted as shown in Figure 1, in base shear-roofdisplacement format and base shear coefficient-global drift ratio format. Both Figures contain 54 structural models, after eliminating the structural models that does not satisfy the minimum modal mass participation ratio of $60 \%$, which is imposed for successful utilization of pushover analysis. The pushover and capacity curves are classified with respect to the number of storeys. After reviewing both Figs 1(a) and (b), it can be said that, the curves follow a divergent pattern in terms of post elastic stiffness and obviously, the structures fail in a brittle and ductile manner. In addition, the failure points have a common feature that they take place at the maximum base shear and maximum roof displacement without any strength degradation.

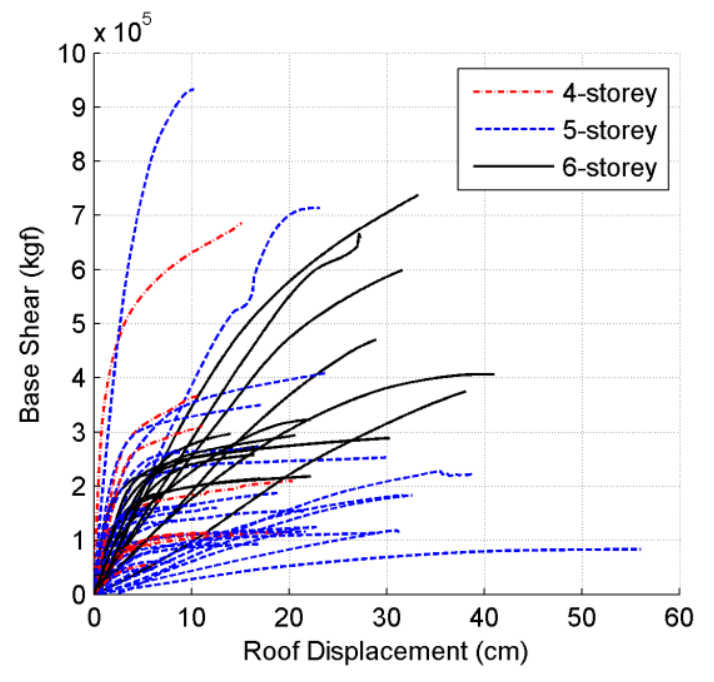

(a)

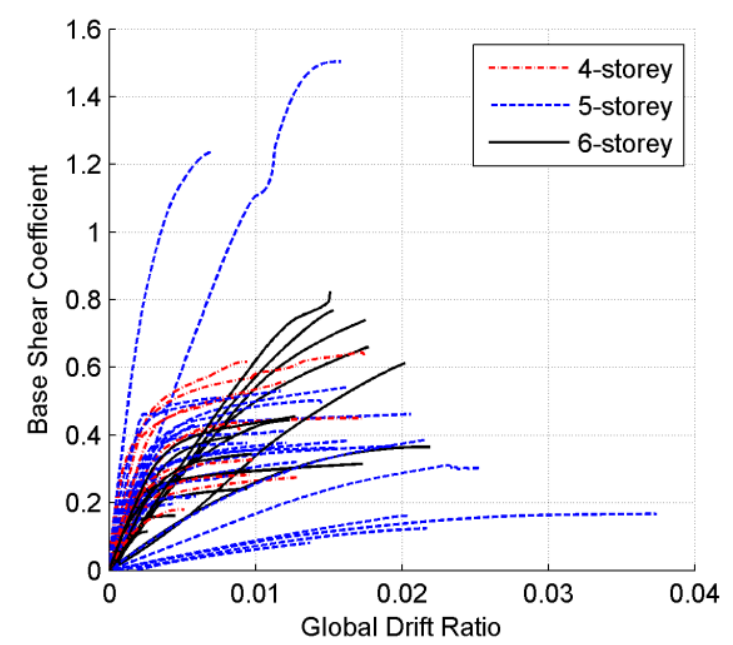

(b)

Figure 1.(a). Pushover Curves (b). Capacity Curves (Total 55 Structural Models)

\subsection{Examination of the Database}

The database is examined for the ranges of the interested structural parameters. In order to explore the relationship between the fundamental period and the height within the sample, Figure 2 is 
generated. The figure demonstrates that, if the outliers are excluded, a pattern of dependency emerges between the height of the structure and the fundamental period. In order to assess the emerging pattern, widely used height- period equations are plotted in the figure as reference [28, 29, 30 and 31].

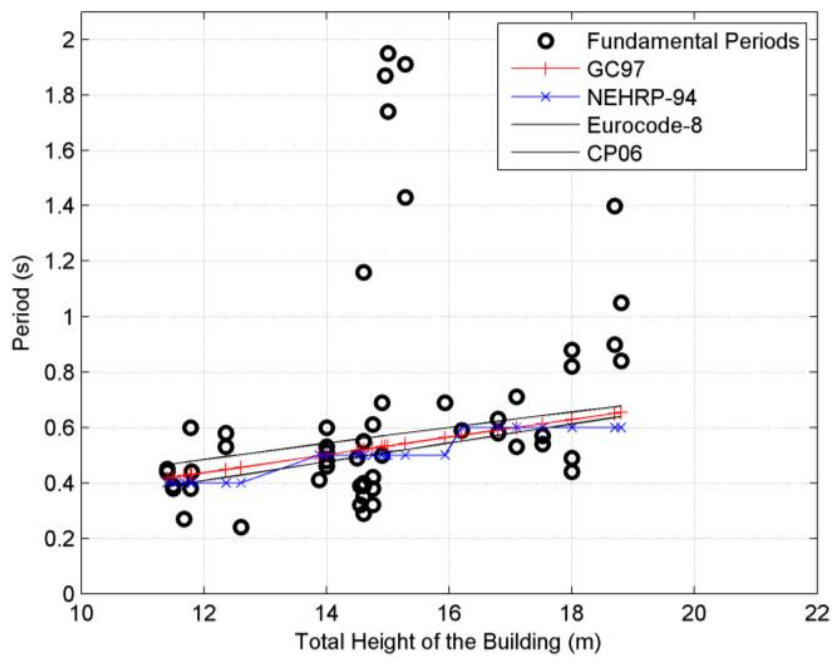

Figure 2. Period versus Height Relationship of All the Buildings and Calculated Periods by Using Different Formulations (Total 54 Structural Models)

Lateral stiffness indexes of the structures display an expected pattern of distribution as shown in the left part of Figure 3. The exponential decrease in the lateral stiffness ratio with respect to the increasing values of fundamental period implies the type of relationship between the lateral stiffness index and the maximum lateral displacement. As for the ductility ratio, it is a known fact that, the ductility ratio of a structure decreases with increasing fundamental period, and as the plot in the right part of Figure 3 confirms, very high and low ductility ratios are observed for low and high fundamental periods. Especially after $1.0 \mathrm{~s}$, a steady pattern exists with slightly fluctuating values.

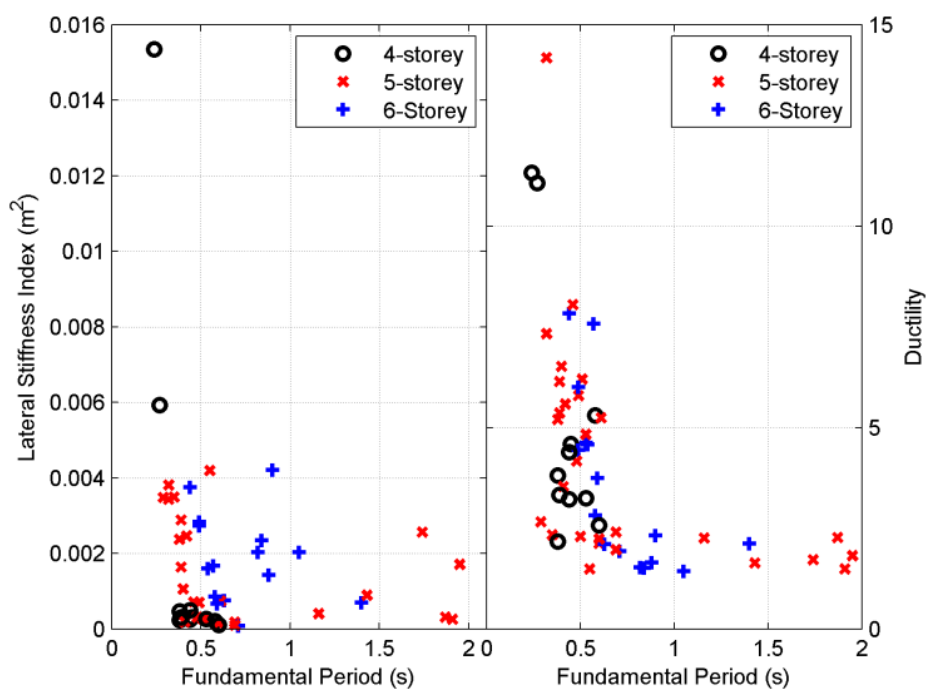

Figure 3. Variation of Lateral Stiffness Index and Ductility Ratio with Respect to Fundamental Period (Total 54 Structural Models) 
Karaca H.

\subsection{Response Spectrum Curve}

The elastics response spectrum curves of [10] are utilized, which are developed for 5\% damping coefficient for the city of Eskisehir. Originally, in the development of the elastic response spectrum curves, ground motion prediction equation of [32] with calibrated coefficient were employed with the site condition accepted as NEHRP B/C boundary [10]. Therefore, considering [26], prescriptions for the use of site-specific seismic hazard maps, the elastic response spectrum curves developed for Eskisehir are modified with the application of site amplification factors to comply with the requirements and reflect the effect of the site conditions, which is accepted as site class $C$. The modification of the original response spectrum curves is performed by using the seismic coefficients of $C_{A}$ and $C_{V}$, wherein $C_{A}$ is defined by the acceleration of the ground at $0.30 \mathrm{~s}$, and $C_{V}$ is accepted as equal to the spectral acceleration value at the period of $1.00 \mathrm{~s}$ [26].

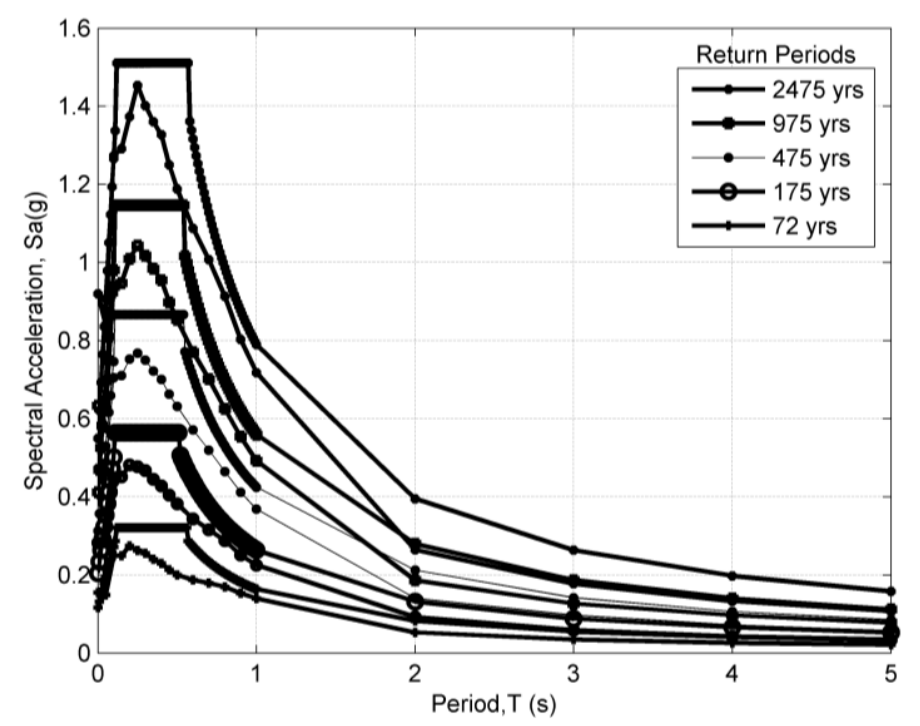

Figure 4. Modified Elastic Acceleration Response Spectrum Curves for Eskisehir

Hence, the simplification of the elastic response spectrum curves is carried out by using two spectral acceleration values that are obtained for each response spectrum curve. As shown in Figure 4, the modified elastic response spectrum curves, which originally are generated for Eskisehir with the damping ratio of $5 \%$, and associated with earthquakes that have $2 \%, 5 \%, 10 \%, 25 \%$ and $50 \%$ exceeding rates in 50 years, are presented.

\subsection{Calculation and Evaluation of Lateral Performances}

By using the response spectrum curves developed for Eskisehir and the structures compiled for this study the performance roof displacements and global drift ratios are calculated. Figure 5 is generated to detect outlier performances or unexpected pattern of behavior. The issue of soft storey and torsional influences over the performance of the structures are checked in order to assure there aren't other parameters that play role in the shaping of lateral performances other than the investigated parameters. As can be observed from all the subplots, there are some models with very high lateral roof displacements, which could initiate an inquiry about the reasons of the nonconformance. If the nonconformance is based on outlier characteristics, such as very hog or low fundamental period, ductility or lateral stiffness index 
then an elimination scheme shall be formulated to refine the database and tune the database into a group of structures with similar and more predictable behavior.

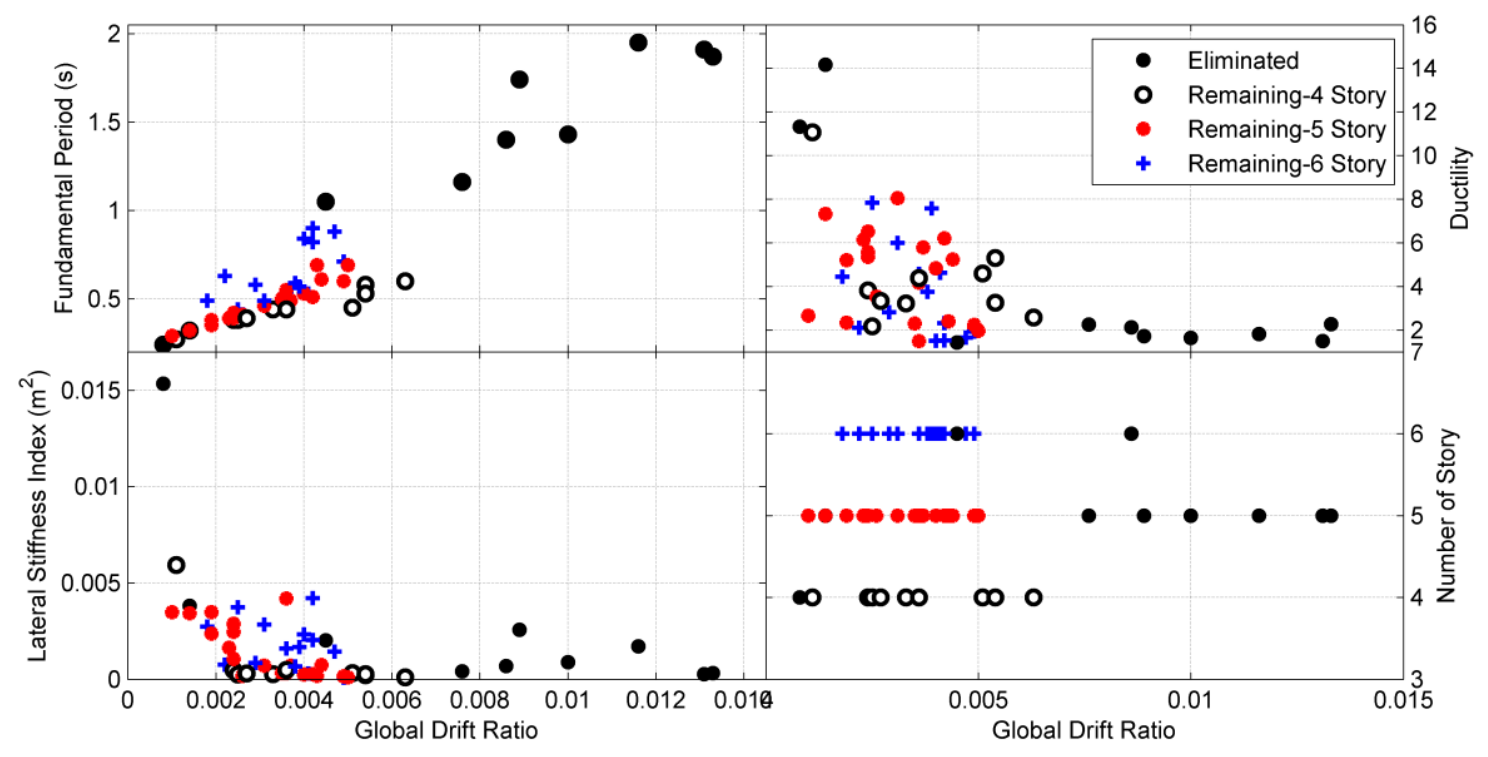

Figure 5. Variation of Performance Global Drift Ratios with Fundamental Period, Ductility, Lateral Stiffness Index and Height Respectively (54 structural models, Performance Drift Ratios Calculated for an Earthquake with 475-year Return Period)

In the evaluation, the patterns of lateral performances with respect to all four parameters are taken into consideration. It is quickly observed that, structural models with fundamental periods greater than $1.0 \mathrm{~s}$, display unpredictable behavior compared to the models with fundamental periods less than 1.0 s. A total of 10 structural models display an outlier lateral performance, 8 of which have fundamental periods greater than $1.0 \mathrm{~s}$, and one with high ductility ratio and the last one with very high ductility ratio and lateral stiffness index at the same time. Hence in order to create a uniform database with uniform lateral performance distribution for the better understanding of the relationship between the investigated parameters and the fragility curves, all the outliers are excluded. After the elimination of the outliers, 45 models remained for further study. It is thought that, the remaining models must be further examined for any adverse influence of the existence of shear walls over the lateral performances. Considering the fact that in most of the time with the right combination of structural elements and building geometry, the existence of shear wall could be the reason for lower fundamental periods in the structural models and causes lower demand displacements, and keeps the structure in the elastic region until for higher global drift ratios. However, knowing that the influence of shear wall on the performance displacements are accounted in IDCM and limit states are determined for each different group regardless of the existence or nonexistence of shear walls within each group, it is not required considering the influence of shear walls to reach to the objectives of the study.

\subsection{Damage Limit States}

The limit states are defined by associating the average yield and ultimate lateral drifts with the predefined damage limit states of immediate occupancy, life safety, and collapse prevention. The average yield lateral drift ratios are associated with the damage limit state of immediate occupancy, while the ultimate lateral drift ratios are used to determine the life safety and collapse prevention limit states. The 
Karaca H.

average values of yield and ultimate lateral drifts are approximately calculated by using the bilinear models [26] of the pushover curves. The approximation of the capacity curves as bilinear models is performed by using the guidelines presented in [26] for the application of the DCM. The ultimate drift ratio is used to establish the life safety and collapse prevention limit states, as the $75 \%$ of the average ultimate drift ratio is assigned to the damage limit state value for life safety [20]. All the values of the global drift ratios at each limit state are provided in Table 1.

Table 1. Damage Limit States for Specific Group of Structural Models with Respect to Predefined Criteria

\begin{tabular}{cccccc}
\hline Parameter & Criteria & $\begin{array}{c}\text { Number of } \\
\text { Models }\end{array}$ & $\begin{array}{c}\text { Immediate } \\
\text { Occupancy }\end{array}$ & Life Safety & $\begin{array}{c}\text { Collapse } \\
\text { Prevention }\end{array}$ \\
No of & 4 & 10 & 0,0029 & 0,0084 & 0,0113 \\
Story (n) & 5 & 21 & 0,0028 & 0,0047 & 0,0063 \\
& 6 & 14 & 0,0025 & 0,0057 & 0,0077 \\
Fundamental & $0,20<\mathrm{t}<0,45$ & 16 & 0,0050 & 0,0086 & 0,0114 \\
Period (t) & $0,45 \leq \mathrm{t}<0,58$ & 14 & 0,0021 & 0,0104 & 0,0138 \\
& $\mathrm{t} \geq 0,58$ & 15 & 0,0027 & 0,0075 & 0,0100 \\
Lateral Stiffness & $0<1 \mathrm{si} \leq 3,1$ & 15 & 0,0023 & 0,0056 & 0,0075 \\
Index (lsi) & $3,1<1 \mathrm{si} \leq 20$ & 16 & 0,0041 & 0,0087 & 0,0116 \\
& $1 \mathrm{si}>20$ & 14 & 0,0033 & 0,0099 & 0,0132 \\
Ductility $(\boldsymbol{\mu})$ & $0<\mu<2,6$ & 15 & 0,0021 & 0,0073 & 0,0097 \\
& $2,6 \leq \mu<5,0$ & 15 & 0,0046 & 0,0078 & 0,0104 \\
\hline
\end{tabular}

\subsection{Fragility Curves}

After deciding on the cumulative distributon function and the ground motion intensity, the lateral performances of the structures at different levels of ground motion are obtained. Then, as presented in Figure 6, these points are used to create performance curves which allows the computation of the ground motion levels at predefined global drift ratios corresponding to different damage states. The figure display 45 performance curves which are generated by using 5 different lateral performances in global drift ratios at different levels of ground motion.

The global drift ratios which are associated with immediate occupancy, life safety and collapse prevention damage states are employed to compute the level of ground motion correponding to the associated damage state. The distribution of the computed ground motion levels for all the strucutral models and for each damage state is assumed as lognormal and the cumulative distribution function is used to generate fragility curves. After that, these fragility curves are regenerated for a number of structural parameters. All the selected lateral performance curves are divided into three different groups which are created by using structural parameters of number of story, fundamental period, lateral stiffness index and ductility ratios. In the grouping, it is sought that each group contains equal or closer number of structural models except for the groups created for number of storeys 


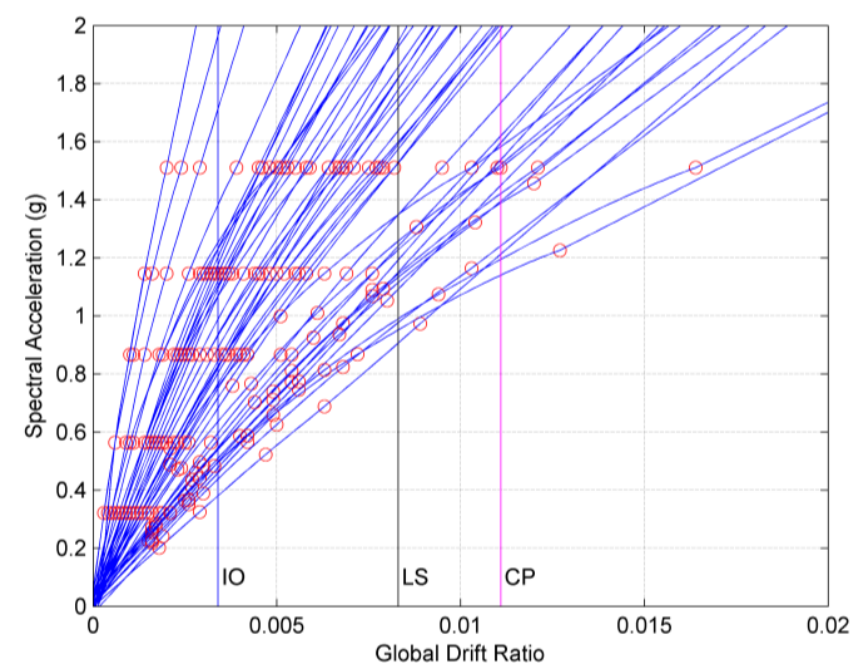

Figure 6. Computation of Lateral Performances for Each Damage State (IO: Immediate Occupancy, LS: Life Safety, CP: Collapse Prevention, Limit States are arbitrarily located)

The number of story, as a structural parameter, doesn't require any complicated analysis to be determined as compared to the fundamental period, lateral stiffness index and the ductility ratios. Hence, in the estimation of the lateral performances and damage ratios, it is very convenient to classify the structures with respect to the number of stories. However, as displayed in Figure 7, this classification might not be reliable at all, since varying number of stories might not follow the expected behavior. Indeed, as presented in Figure 2, the consistency of the fundamental period and the height is assured by removing the structural models with fundemantal periods greated than $1.0 \mathrm{~s}$. Therefore, it was expected that a pattern would emerge between the number of storeys and the maximum lateral displacement. Knowing that, number of storey is used to classify the buildings in the development of fragility curves, and this finding claims otherwise, an explanation is required. The underlying reason for this could be the disproportional relationship between the number of story and global drift ratio.

As shown in Figure 8, though the roof displacements are positively proportional with respect to the the number of story, the global drift ratio versus number of story relationship display a fluctuation. Moreover, as the number of storey increases, the demand displacements are subjected to increase as all the structural models lie within the velocity sensitive ragion of the response spectrum curve, however the rate of increase in the demand displacement and the performance displacement obviously is not high enough to satisfy a sufficient increase in the global drift ratios that would assure higher damages for higher number of stories. Moreover, varying damage limit states also contribute to the obtained disproportionality of the damage ratios with respect to the number of stories. 


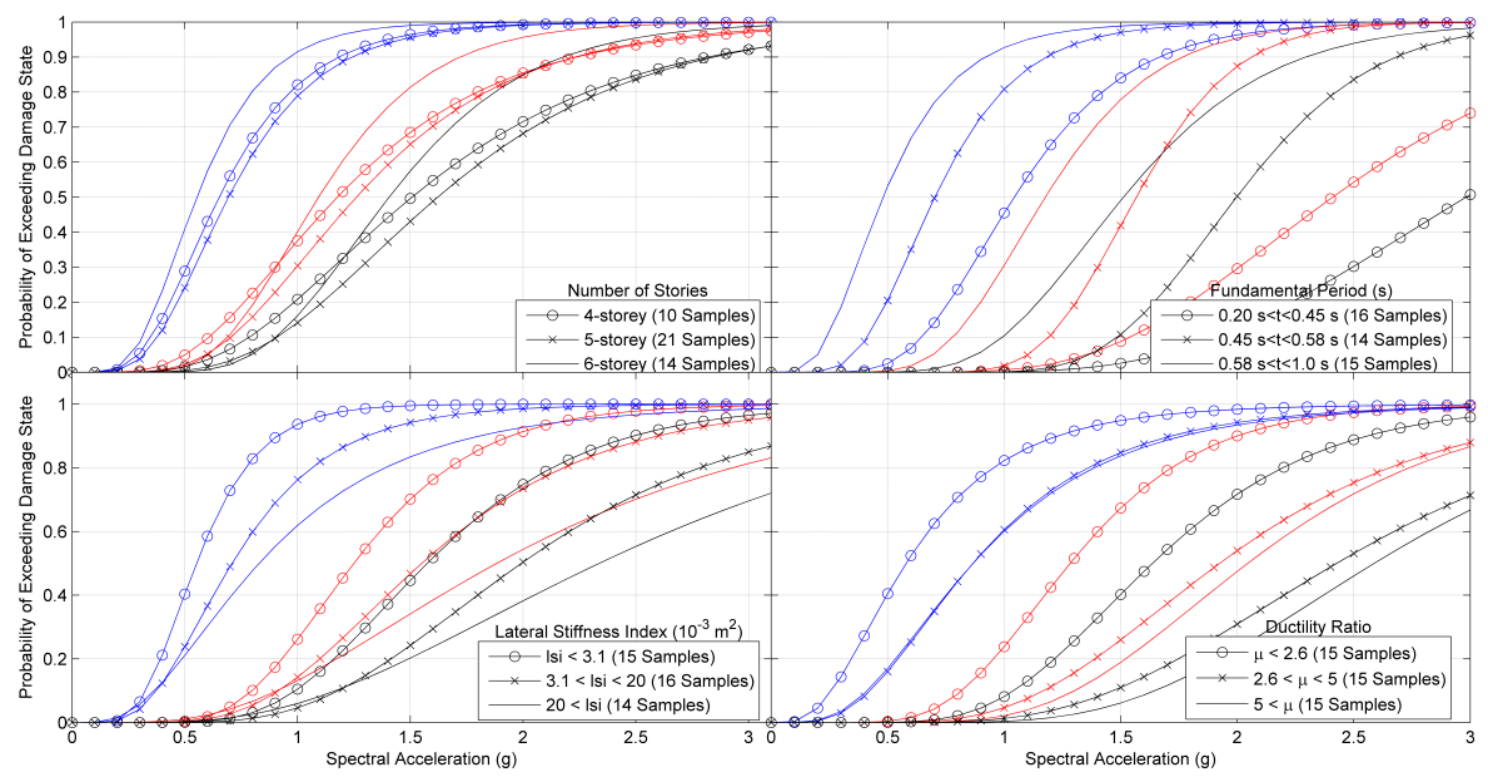

Figure 7. Fragility Curves Obtained for Different Number of Stories, Varying Ranges of Fundamental Period, Lateral Stiffness Index and Ductility (Spectral Acceleration as Ground Motion Parameter, Blue: Immediate Occupancy, Red: Life Safety, Black: Collapse Prevention, 45 Models

Fundamental period is more directly related to the lateral performance than number of stories. It is used to determine the demand displacement which indeed is modified by IDCM to obtain the performance displacement. For the fragility curves, it is expected that, models with higher fundamental periods display higher damage ratios for the same level of spectral acceleration and for almost all cases. Only if the distribution of the structural models with respect to other influential structural parameters, such as ductility, is not balanced, than an unexpected pattern might be obtained. In other words, compared to the models with higher fundamental periods, models with lower fundamental periods require higher demand accelerations to reach to the same level of damage limit state. Therefore, knowing that, all the structures are within the velocity sensitive region, the fragility curves displayed in Figure 8 is easily justified with models follow the expected behavior.

Lateral stiffness index, has a complicated influence over the lateral performance. As the fundamental period of a structure depends on the lateral stiffness and mass of a structure, it should be expected that, if a large sample is provided, structures with higher lateral stiffness index have lower fundamental periods. As expected, structural models with higher lateral stiffness indexes display lower damage ratios for the same ground motion level in terms of spectral acceleration as shown in Figure 7.

At the right bottom subplot in Figure 7, fragility curves obtained for three different groups with varying ductility ratios are displayed. The dependency of the lateral performance to the ductility ratio is also complicated, which indeed intuitively cannot be deduced without much experience. Structures with higher ductility tend to have lower fundamental periods and exposed to lower demand displacements, which in turn lowers the damage ratio, hence it is highly likely that they would be less prone to the damages. As the Figure implies, it requires higher demand accelerations for structural models with high ductility ratios to reach to the same level of damage limit state when compared to the structural models with lower ductility ratios. 


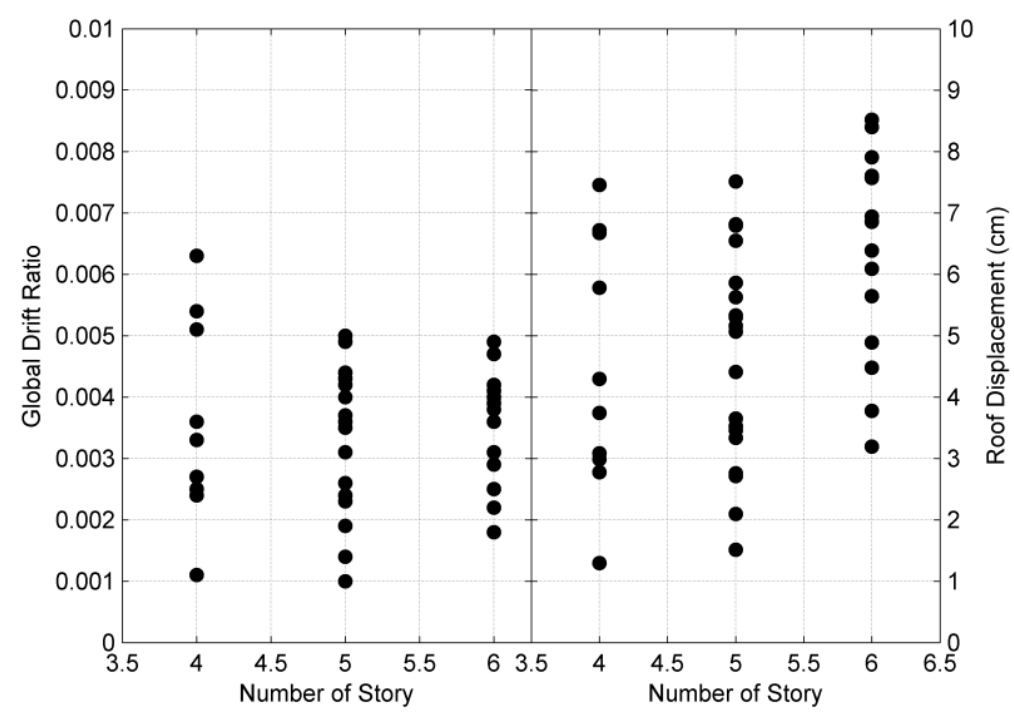

Figure 8. Performance Roof Displacements and Global Drift Ratios for an Earthquake with 475-year Return Period with Respect to Varying Number of Stories

\section{Conclusion}

The purpose of developing fragility curves was to be able to quantify the structural performance at least statistically so that there would be a chance to evaluate the structural performances of various buildings or building types. Though, the underlying assumptions in the development of these curves are still questioned, it is still commonly accepted in the determination of structural performances in terms of predefined structural parameters. Knowing that there are several structural parameters that shape the structural performance, it is expected that the structures with similar would behave in a similar manner. Moreover, as the fragility curves developed by using the statistics, similiarly, in the same manner, various building classifications can be identified by using the structural parameters as well. This study intended to develop a classification scheme based on the fundemantel period, lateral stiffness index, ductility and number of storeys. In order to put it simply, fragility curves were derived for existing reinforced conctere structures in Turkey as a function of groups of structures with respect to number of stories, fundamental periods, lateral stiffness index and ductility ratios.

As a major finding of this study, classification of buildings with the number of storeys and expecting their performances with respect to the number of storeys might not be reliable at all. It is thought that in order to obtain the assumed behavioral patterns, certain structural criteria must be met. Therefore, before classifying the buildings with respect to any of the structural or geometrical parameters, one must investigate the parameters that could influence the lateral performance other than number of stories.

Second major finding is that, the alignment of fragility curves to the fundamental period, lateral stiffness index and the ductility ratio is justified as the lateral performance pattern of the structures with respect to the mentioned parameters follow a meaningful course. At first, it could be easly said that the composition of the structures in the sample allowed for such an alignment of the lateral performances with respect to the mentioned structural parameters, however with a closer look, especially to the distribution of the lateral performances with respect to the global drift ratios shown in Figure 5, the results 
can be justified. Finally, it is revealed that, the variance of the lateral performance with respect to the mentioned parameters is very well reflected with the spectral acceleration used as ground motion intensity.

All these findings lead to a justification of statistical approach in the determination of the lateral performances of buildings. Clearly, for the evaluation of large number of buildings, it is very time consuming to compute the lateral performance of each building to determine the overall performance and the samples might never be large enough to decide on the classification scheme. Either way, the statistical approach offers the only solution for the evaluation of the lateral performances if any pattern shall be investigated between the abstract or physical structural parameters and the lateral performances. It shouldn't be forgotten that the relationship between the physical structural parameters such as number of storeys or abstract structural parameters such as fundamental period, ductility or lateral stiffness index with the lateral performances might be very complex and interdependent. Hence, the dependency of the lateral parameters to the structural parameters might be investigated by using large number of buildings and through a set of combination of these parameters as well.

\section{References}

[1] Whitman R.V., Reed J.W., Hong S.-T., "Earthquake damage probability matrices". Proceedings of the fifth World Conference on Earthquake Engineering,pp. 2531, Rome, 1974.

[2] ATC-13 "Applied Technology Council "Earthquake damage evaluation data for California", Redwood City, California, 1985.

[3] Calvi G.M.: "A displacement-based approach for vulnerability evaluation of classes of buildings". Journal of Earthquake Engineering, Vol.3, No. 3,1999.

[4] FEMA-440 "Improvement of Nonlinear Static Seismic Analysis Procedures" Federal Emergency Management Agency Report, FEMA.440, Washington D.C., USA, 2004

[5] Brun, J., Kostem, C.: Lateral deflection prediction of concrete frame-shear wall system, Technical Report No: 433-6 Fritz Engineering Laboratory, Lehigh Univ., USA, 1986

[6] ATC 14 "Evaluating the Seismic Resistance of Existing Buildings", Applied Technology Council, Redwood City, California, 1987

[7] FEMA P-154, "Rapid Visual Screening of Building for Potential Seismic Hazards: A Handbook", Federal Emergency Management Agency Report, FEMA.P-154, Washington D.C., USA, 2002

[8] FEMA-P-155, "Rapid Visual Screening of Buildings for Potential Seismic Hazards: Supporting Documentation, Federal Emergency Management Agency Report, FEMA.P-155, Washington D.C., USA, 2015

[9] Albayrak U., Canbaz M., Albayrak G., "A rapid seismic risk assessment method for existing building stock in urban areas" International Conference on Sustainable Design, Engineering and Construction, Procedia Engineering , 118 :1242 - 1249, 2015

[10] Karaca, H., "Estimation of Potential Earthquake Losses for the Evaluation of Earthquake Insurance Risks", METU Civil Engineering Dept., Ph.D. Thesis, 321s, Ankara,Turkey, 2014 
[11] Newmark N.M. and Hall W.J., "Earthquake Spectra and Design", Monograph, Earthquake Engineering Research Institute (EERI): Oakland, California, USA, 1982

[12] Vidic, T., Fajfar, P., Fischinger M., "Consistent Inelastic Design Spectra: Strength and Displacement", Earthquake Engineering and Structural Dynamics, (23)5, 507-521, 1994

[13] Ozcebe G., Yucemen M.S., Aydogan V., Yakut A., "Preliminary Seismic Vulnerability Assessment of Existing Reinforced Concrete Buildings in Turkey-Part I: Statistical Model Based on Structural Characteristics", in: Seismic Assessment and Rehabilitation of Existing Buildings, Kluwer Academic Publishers-KAP, Doortrecht, Netherlands,2003

[14] Gulkan, P. L. and Utkutuğ, D., "Minimum Design Criteria for Earthquake Safety of School Buildings", Türkiye Mühendislik Haberleri, (425)3, 13-22, 2003

[15] Gunel A.O., "Influence of the Shear Wall Area to Floor Area Ratio on the Seismic Performance of Existing Reinforced Concrete Buildings", METU, Civil Engineering Dept., M.Sc. Dissertation, Ankara, Turkey, 2013

[16] Burak B. and Comlekoglu H.G., "Effect of Shear Wall Area to Floor Area Ratio on the Seismic Behavior of Reinforced Concrete Buildings", Journal of Structural Engineering ASCE, (139)11, 1928-1937, 2013

[17] Shinozuka M., Feng M. Q., Lee, J., and Naganuma, T., "Statistical analysis of fragility curves", Journal of Structural Engineering, 126, 1224-1231, 2000

[18] Pitilakis K., Weatherill G., Crowley H., Pinho R., "Systematic Seismic Vulnerability and Risk Analysis for Buildings, Lifeline Networks and Infrastructures Safety Gain", Deliverable D2.12, 2011

[19] Erberik M.A. and Elnashai A.S., "Fragility Analysis of Flat Slab Structures", Engineering Structures, 26, 937-948, 2004

[20] Akkar S.,Sucuoglu H., Yakut A., "Displacement Based Fragility Functions for Low and Mid-rise Ordinary Concrete Buildings", Earthquake Spectra,(21)4, 901-927, 2005

[21] Ay B.O. and Erberik M.A., "Vulnerability of Turkish Low-Rise and Mid-Rise Reinforced Concrete Frame Structures", Journal of Earthquake Engineering, (12) S2, 2-11, 2008

[22] Erberik M.A., "Fragility Based Assessment of Typical Mid-Rise and Low-Rise Reinforced Concrete Buildings in Turkey", Engineering Structures, (30)5, 1360-1374, 2008

[23] Kircil M.S., and Polat Z., "Fragility analysis of mid-rise R/C frame buildings", Engineering Structures., (28)9, 1335-1345, 2006

[24] Ucar T. and Duzgun M., "Betonarme Binalar İçin Artımsal İtme Analizi Esaslı Analitik Hasar görebilirlik Eğrilerinin Oluşturulması", Teknik Dergi, (24)3,6421-6446 (In Turkish), 2013

[25] Computers and Structures, Inc., SAP 2000 Version 15, Structural Analysis Program, Berkeley, CA, 2000

[26] ATC-40, "Seismic Evaluation and Retrofit of Concrete Buildings", Applied Technology Council, California, USA, 1996 
Karaca H.

[27] NEHRP Guidelines for Seismic Rehabilitation of Buildings. Federal Emergency Management Agency Report: FEMA 273. Washington D.C.,USA, 1997

[28] NEHRP, Recommended Provisions for the Development of Seismic Regulations for New Buildings. by the. Building Seismic Safety Council, Washington, D. C.,USA, 1994

[29] EuroCode 8,, Design of Structures for Earthquake Resistance, CEN, Brussels, 2004

[30] Goel R.K. and Chopra A.K., "Period Formulas for Moment-resisting Frame Buildings", Journal of Structural Engineering ASCE, 11, 1454-1461, 1997

[31] Goel R.K. and Chopra A.K., "Period Formulas for Concrete Shear Wall Buildings", Journal of Structural Engineering ASCE, 4, 426-433,1998

[32] Akkar S. and Cagnan Z., "A Local Ground Motion Predictive Model For Turkey And Its Comparison With Other Regional And Global Ground-Motion Models", Bulletin of Seismological Society of America, 100, 2978-2995, 2010

\section{List of Notations and Abbreviations}

$C_{A} \quad:$ Spectral Acceleration at $0.30 \mathrm{~s}$

$C_{V} \quad:$ Spectral Acceleration at 1.00

$C P \quad$ : Collapse Prevention

DCM : Displacement Coefficient Method

IDCM : Improved Displacement Coefficient Method

IO : Immediate Occupancy

LS : Life Safety

lsi : Lateral Stiffness Index

$n \quad$ : Number of Storeys

$\mathrm{Sa} \quad$ : Spectral Acceleration

$t \quad$ : Fundamental Period

$\mu \quad$ : Ductility Ratio 